\title{
Sharing the wealth
}

\author{
Issues of public education and outreach \\ in museum research libraries
}

\author{
by Margaret R. Dittemore
}

$I^{\prime \prime}$ discussions among librarians in teaching institutions concerning the role of research librarians in education and public service, the museum library community is often overlooked. Yet museums were established in the United States with education as a primary mission, and outreach has a long and distinguished role in their history.

In recent years, with advances in technology and the changing roles of both stewards and stakeholders, museums and the libraries within them have become increasingly active in conducting multiple programs to inform and serve diverse audiences.

A brief look at one museum library's experiences offers a window into this broad commitment to outreach and education, particularly by

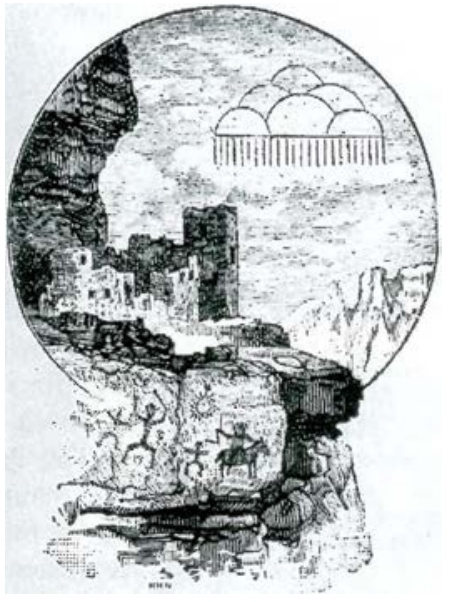

The Smithsonian's Bureau of American Ethnology colophon found on the title pages of many publications. archives have ... to share the wealth of their resources with the descendants of those people who created that wealth."1

Founded in 1846 through the bequest of a wealthy English scientist, the Smithsonian Institution is funded today primarily by U.S. taxpayers' dollars. Its mandate - to promote the "increase and diffusion of knowledge" - has led to more than 150 years of significant research, the building of unparalleled collections, and an active, national program of public education and outreach.

The Smithsonian Institution Libraries (SIL) and its predecessors have played an integral part in this effort. ${ }^{2}$ The John Wesley Powell Library of Anthropology, a SIL branch, has had a special place. Its collections and services reflect the formative role that the Smithsonian has those libraries with stewardship over publicly held collections. It is also an opportunity to consider the special responsibility all "Constitutions such as museums, libraries, or had in the development of American anthropology as a discipline and its long history of research and collecting in this area all over the world.

\section{About the author}

Margaret R. Dittemore is head of the John Wesley Powell Library of Anthropology, Smithsonian Institution Libraries, e-mail: dittemorem@sil.si.edu 


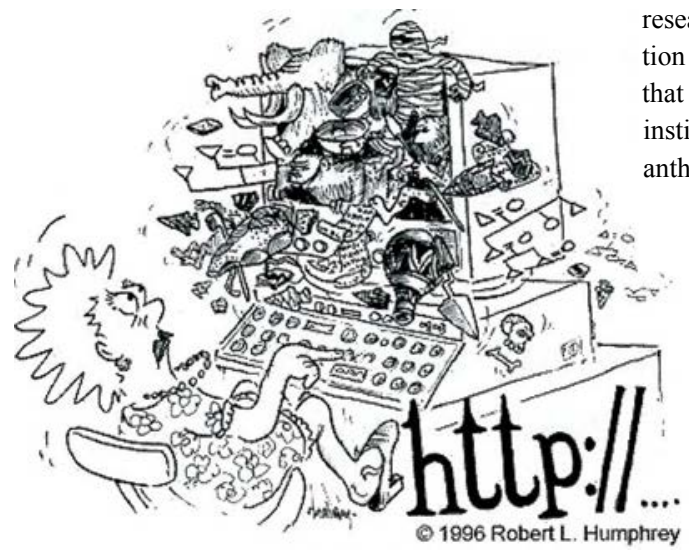

"Anthropology on the Internet for K-12," a Web site for students and teachers compiled and maintained by the Smithsonian's Anthropology Library.

Of particular note is the library's strength in the study of Native American history, language, and culture resulting from huge collections amassed by the Smithsonian and extensive fieldwork conducted and published in this area, most prominently through its Bureau of American Ethnology. ${ }^{3}$ Today this material is preserved in the museum's anthropological collections, with the published materials under the stewardship of the Powell Anthropology Library.

\section{Serving many constituencies}

As a part of SIL, the Powell Anthropology

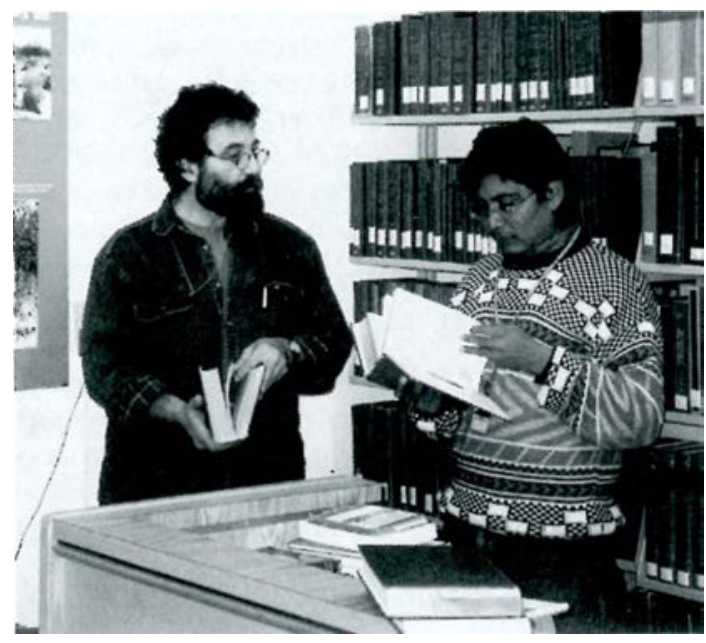

A Kuna Indian from Panama consults with a researcher in the library.
Library's primary mission is to support the research and information needs of the institution while sharing the wealth of information that it holds in trust as a publicly supported institution with the nation. Because of anthropology's strong appeal to the general public, the library serves an especially broad range of patrons. Requests for support and information come from local, national, and international clientele, including students, educators, and other scholars, magazine and book publishers, artists, picture researchers, hobbyists or craftspeople, interested laypeople, and museum visitors who have seen an exhibition or heard a talk that sparks their interest.

Larger groups are also regularly served, such as government agencies, professional and educational organiza-

tions, news agencies, special-interest groups (such as those concerned with conservation and indigenous populations), and other museums.

The core of its service to these wide-ranging groups is SIRIS, or the Smithsonian Institution's Research Information System (http://www.siris.si.edu), which includes the online library catalog; the SIL homepage (http://www.sil.si.edu) with information about its collections and services; and an active e-mail reference service (libmail@sil. si.edu). Moreover, it participates in resourcesharing nationally and internationally, a long and time-honored tradition among all libraries and a true example of public outreach.

The Powell Anthropology Library also maintains a branch Web page of its own (http://www.sil.si.edu/ Branches/anth-hp.htm), which offers virtual audiences easy access to Smithsonian Internet resources in anthropology and a Web page, Anthropology on the Internet for K-12 (http://www.sil.si.edu/SILPublications/ Anthropology-K12/anth-k-12-

home.htm), which introduces young people (including college students) and their teachers to the field.

The site is illustrated with photos of Smithsonian anthropologists at work in the field or in their labs and with objects from the Smithsonian anthropol- 
ogy collections. The close day-to-day relationships with researchers that librarians in a museum enjoy facilitate such collaboration and support, especially in public education and outreach efforts.

A second such cooperative effort is Smithsonian Expeditions (http://www.nmnh. si.edu/anthro/laexped), a multimedia, bilingual Web site integrating library, archival, and object collections to present an overview of 150 years of Smithsonian research in Latin America.' ${ }^{1}$

\section{Among the stakeholders ...}

Among the wide range of patrons who frequent SIL's Powell Anthropology Library is a special group of stakeholders whose heritage is closely tied to the Smithsonian's history and collections. Although such a clientele is not unique to museums, museum librarians probably interact with these patrons much more often than their academic counterparts.

Prominent among this clientele are native peoples from all over the world, especially from the

Americas. Often they arrive in conjunction with visits to the Anthropology Department's National Anthropological Archives (http:// www.nmnli.si.edu/naa), its Office of Repatriation (http://www.nmnh.si.edu/anthro/ repatriation), or its Tribal Catalog Project. They may be working on repatriation efforts or language revitalization programs, seeking documentation for tribal recognition efforts, music, legends and art for school programs or cultural heritage centers, or simply hoping to find a picture of an earlier family member.

Similarly, there is a smaller group of people whose ancestors worked for or had contact with the Smithsonian as researchers, missionaries, explorers, traders, and the like, usually among native peoples. Recent examples include a woman in Italy seeking more infor- mation about her great-grandfather, a missionary among the Blackfeet Indians in the Rocky Mountains; and another seeking to complete fragmented childhood recollections of her great uncle, a modest, but prolific, Smithsonian researcher in both the Arctic and Mexico.

Many of these stakeholders share deeply moving experiences as they uncover their past and plan for their future. Their knowledge and/ or research substantially adds to our own understanding of these records and makes us aware of their present-day meaning and importance. Related to this clientele are the Smithsonian researchers themselves who rely on the library and its resources in their own

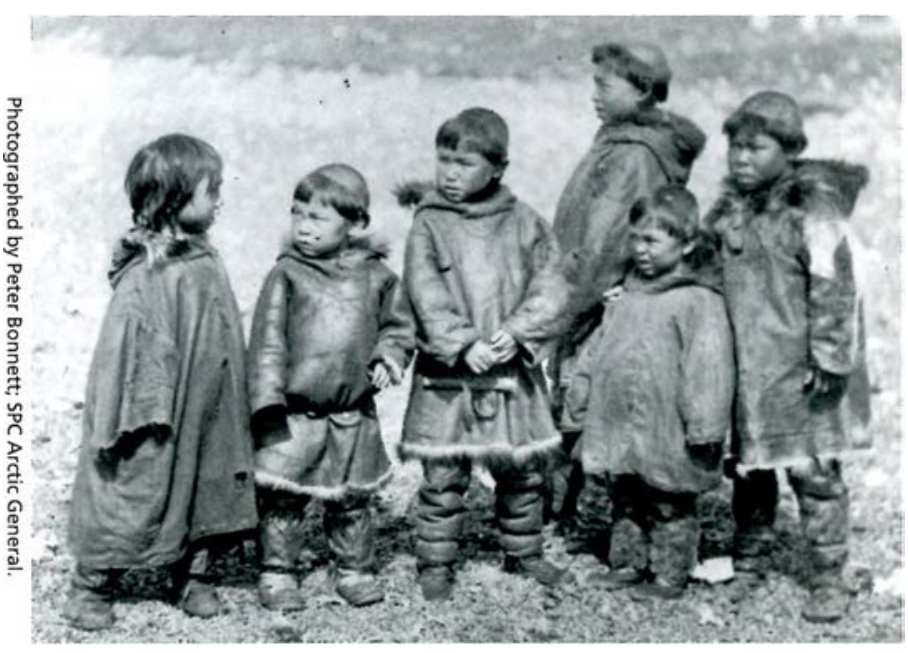

t. Lawrence Island children in the 1880s.

For example, the Repatriation Office documents museum collections and materials that have been requested for return by Native American tribes as part of the Native American Graves Protection and Repatriation Act (NAGPRA). When complete, much of the documentation becomes part of the Powell Anthropology Library's own collection, enriching it and enabling both the office and the library to fulfil their basic missions.

A final example, notable especially from the library view point, is the work of "knowledge repatriation," as one researcher and his colleagues call it. With the help of a National Science Foundation grant, they are "returning" historical knowledge to the Beringian Yupik communities on St. Lawrence Island, 
Alaska (and neighboring Chukotka, Russia), a region where the Smithsonian conducted extensive research and collecting over a number of generations. "Libraries [and] governmental and local archives abound in all sorts of valuable historical documentation," says Igor Krupnik, the principal investigator on the project. ${ }^{5}$

Although routinely used by scientists, Krupnik believes that the written record remains poorly known and largely inaccessible to many local people who have a vested interest in it. As a result, he is collecting copies of photos, fieldnotes, genealogies, publications, census materials, and the like - the work of scientists, teachers, missionaries, and government officials over the past 120 years - for return to those Alaskan native people whose ancestors helped to generate them.

His goal is to prepare this material as small, local collections for access and use in heritage, educational, and community programs. By engaging a new generation in its own history, Krupnik and the libraries and archives

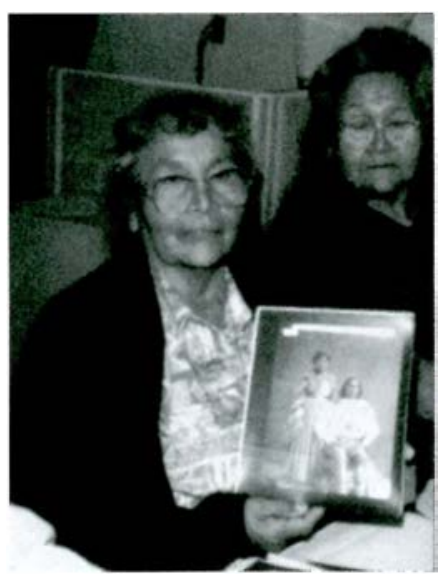

An Apache woman visiting the National Anthropological Archives finds photos of her parents.

\section{Notes}

1. Joallyn Archambault, personal communication, 1996. Archambault is head of the American Indian Program, Department of Anthropology, National Museum of Natural History, Smithsonian Institution.

2. Nancy E. Gwinn, "The Smithsonian Institution Libraries: Afoot in Three Camps," College \& Research Libraries 50, no. 2 (1989): 206 214. See also Margaret R. Dittemore, "Smithsonian Institution Libraries (SIL): Anthropology Branch," in Anthropological Resources: A Guide to Archival, Library and $\mathrm{Mu}$ seum Collections, ed. Lee S. Dutton (New York: Garland Publishing, 1999), 147-152.

3. For more infonnation, see Curtis Hinsley, The Smithsonian and the American Indian: Making a Moral Anthropology in Victorian America (Washington, D.C.: Smithsonian Institution Press, 1994). An online index to all publications of the Bureau of American Ethnology (BAE) is among the Smithsonian Institution Libraries' offerings at http://www.sil.si.edu/

Digital Collections/BAE/ baehome.htm.

4. This site is based on an with which he works are "boost(ing) the education and cultural awareness in places and communities where (this material) was collected generations ago."6

\section{Conclusion}

As part of the long tradition of Smithsonian anthropology, the John Wesley Powell Library of Anthropology is sharing its resources with the descendants of those who helped to create them and all those who seek to learn from this enormously rich legacy. Its activities are examples of how many museum research libraries-especially those with stewardship over publicly held collections-reach out to people everywhere as part of their broader commitment to public service and education. By sharing this wealth, libraries help to facilitate research, the growth of the public record, and the preservation of those very resources on which we all rely. actual exhibition hosted by the Inter-American Development Bank in Washington, D.C., in late 1996 and a beautifully illustrated bilingual catalog published for that event titled $E x$ peditions: 150 Years of Smithsonian Research in Latin America. Expediciones: 150 años de investigaciones de la Institucion Smithsonian en America Latina. A revised and substantially enlarged version of this exhibition now appears at the Miami Museum of Science.

5. Igor Krupnik, "Historical Knowledge Prepared for 'Return' to Beringian Yupik Communities," Arctic Studies Center Newsletter 7 (Aug. 1999): 8-9. See also Igor Krupnik, "Recaptured Heritage: Historical Knowledge of Beringian Yupik Communities," Arctic Studies Center Newsletter8 (August 2000): 9-10. The Newsletter is published by the National $\mathrm{Mu}-$ seum of National History, Smithsonian Institution. Also view the Arctic Studies Center Web site at http://www.nmnh.si.edu/arctic.

6. Ibid. 


\section{Find it. Faster.}

You just got a request for a list of grocery stores in a three-state area with more than 20 employees.

You could search through dozens of reference sources to create that list. Or, you could call the Library Division of infoUSA.

We offer the country's most extensive databases of business and residential information. And, you choose the format you want: print, CD-ROM or via the Internet.

Want more information? Call us today at 1-800-808-1113 or e-mail: library@infoUSA.com.

Your search is over.

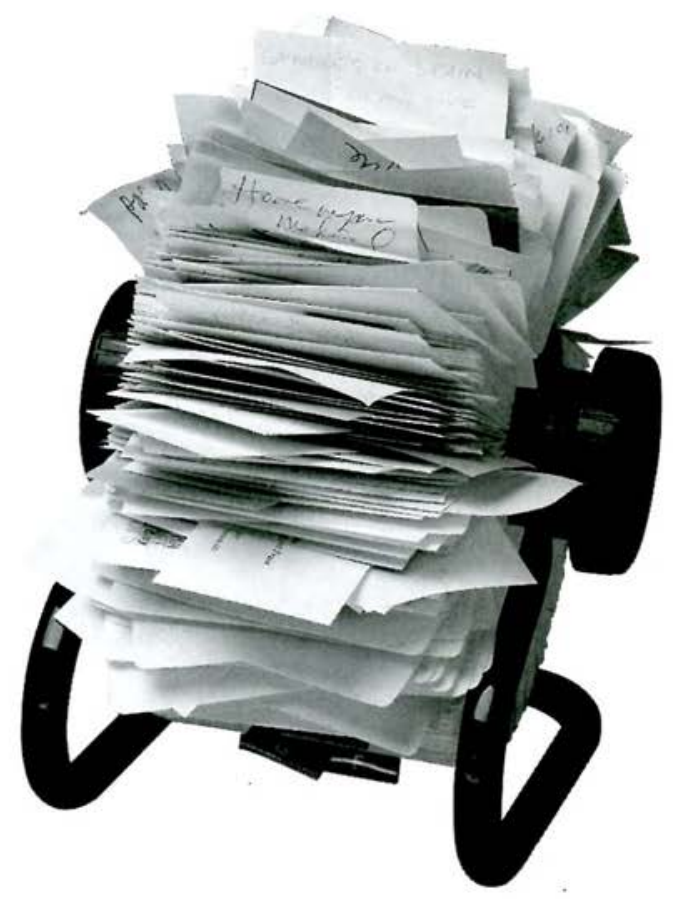

\section{info USA \\ Library Division

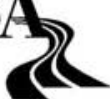

5711 S. 86th Circle • P.O. Box $27347 \cdot$ Omaha, NE 68127

Phone: (402) 593-4523 • Fax: (402) 596-7688 • www.libraryUSA.com

23580 


\section{BIOSIS Previews}

\section{Family of Products}

including Biological Abstracts ${ }^{\circ}$

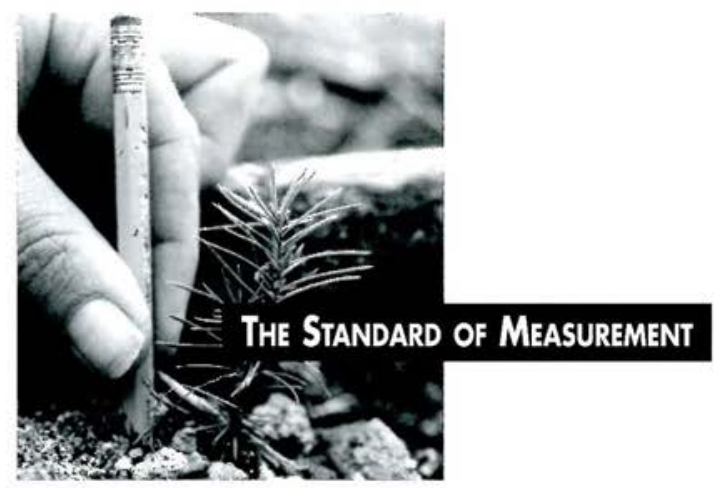

You can find references to life science literature in a variety of databases, but there is one source that is completely indispensable: BIOSIS Previews.

BIOSIS Previews, with its exhaustive review of research literature and comprehensive indexing methods, is the perfect complement to any library collection, and includes:

- An archive of more than 13 million records

- Half a million new records

- References to more than 5,000 serials

every year

- Represents more than 90 countries

BIOSIS Previews is the standard by which all other life science databases must be judged. Found in corporate and academic libraries around the world, BIOSIS Previews is the research tool of choice for professionals who need to know about anything in the life sciences, including:

- Researchers

- Librarians

- Information Specialists

- Product development experts
- Competitive intelligence professionals

- Faculty

- Students

- Legal Experts

\section{www.biosis.org}

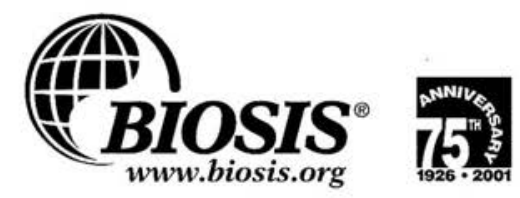

$+1-800-523-4806$ (USA and Canada); +1-215-587-4800 (Worldwide); fax+1-215-587-2016; info@mail.biosis.org

BIOSIS Previews ${ }^{\circ} \cdot$ Biological Abstracts $^{\circ}$ - Zoological Record • MethodsFinder ${ }^{\circ}$ Biological Abstracts/RRM ${ }^{\circ}$ (Reports, Reviews, Meetings) 